\title{
Criticizing the Qur'anic Anthropology of Mu'tazila, Focusing on the Issue of the Superiority of Angels over the Prophets (PBUT) According to the Principles of Ayatollah Jawādī Āmulī
}

\author{
Mahmud Seyedy* ${ }^{1}$, Muhammad Amin Bahrami ${ }^{2}$ \\ ${ }^{1}$ Assistant Professor of Shahed University, Tehran, Iran \\ ${ }^{2}$ Lecturer of Bushehr University of Medical Sciences, Iran \\ Email: m.saidiy@yahoo.com*; mabahrami136@gmail.com
}

http://dx.doi.org/10.18415/ijmmu.v6i5.1067

\begin{abstract}
Prophetology and angelology are one of the main issues mentioned in the Holy Quran. But the question is which of the virtues is superior to the other in terms of the Qur'anic verses when comparing the good qualities of the angels and the prophets and according to the principles and fundamental of virtue ethics in Qur'an? The Mu'tazila believe that because of being preceded in some Qur'anic verses, the absence of evil attributes and their infallibility, the difficulty of worship and the being the Messenger; the angels have absolute superiority and virtue over the prophets. According to Ayatollah Jawādī Āmulī's interpretative-theological principles, due to the divinity of the different names of the prophets, the absolute and inclusive infallibility, the singularity of the angels and the material life of the prophets, the intercession of angels in some types of revelation, not all of them, the reasons of the Mu tazila faces serious challenges and thus the virtue and superiority of the Prophets (peace be upon them) are proved.
\end{abstract}

Keywords: Mu 'tazila; Jawādī Āmulī; angels, prophets; virtues

\section{Introduction}

The Holy Quran is a source of inspiration to Muslim scholars on various scientific issues. So that thoughtfulness in divine revelations has led to the formation of various theories in Islamic sciences. In this regard, various schools of thought and interpretations offered different theories about divine revelations and related issues.

Prophetology (anthropology) and angelology are one of the main themes of the Holy Quran and these two issues are repeated in many verses. So that these issues are closely related to each other. Because revelation and inspiration to the prophets are always done through divine angels and the angels are responsible for doing a lot of things in the creation system such as helping the prophets, dividing the daily bread and so on. 
One of the issues that has caused a great deal of difference between the intellectual and commentary schools in the Islamic world is that when comparing the virtues and good traits of the angels and the prophets (AS), which one is preferred over the other due to the Qur'anic verses? In other words, the Qur'an considers both groups to have many virtues; the question then is which virtues are superior to the other according to the foundations and principles of virtue ethics in the Qur'an. However, all Islamic thinkers agree that angels are superior to ordinary human beings, and the prophets (AS) are lower than the angels and have more virtues. For this reason, the main issue concerns the high-ranking angels and the prophets (Jurjani, 283: 8: 1325).

Among the Islamic thinkers and commentators, the Mu'tazila believe that the angels are virtuous over the prophets (AS) and rely on numerous Qur'anic verses to prove this. In the present study, by using Ayatollah Jawādī Āmulī's interpretive-theological foundations, the Mu'tazila view of this field is criticized and it is proved that according to the anthropological and prophetic principles of the Holy Quran on the one hand and the foundations of virtue ethics in divine verses; the virtues of the prophets are superior to the good attributes of the angels.

\section{The Precedence of the Angels to the Prophets in the Qur'anic Verses}

In some Qur'anic verses, angels take precedence over the prophets (AS), which means their virtue from the point of view of the $\mathrm{Mu}$ 'tazila thinkers. Their arguments are as follows:

[1] The angels are superior to the prophets in worship. Because they have all the good qualities and they are inspired by God to the Prophets. The existence of such superiority proves their virtue because of the verse: "And those Foremost (in Faith) will be Foremost (in the Hereafter). These will be those Nearest to Allah." (Al-Waqi'a: 10-11) (Amidi, 4: 1423: 228) And for the sake of the Nabawi narrative "The one, who establishes a good tradition, has a reward, and he has the reward of those who perform this good tradition." (Suyūṭi, 1404: 5: 260). So the angels have all the virtues and attributes of the prophets. Because before the creation of the prophets, the angels also worshiped God (Rāzī, 2: 1986: 186).

Critique: The Holy Qur'an has divided human beings into three groups: the foremost ${ }^{1}$, the Companions of the Right Hand ${ }^{2}$, and the Companions of the Left Hand: "And ye shall be sorted out into three classes" (Al-Waqi'a: 7). The Companions of the Left Hand, also referred to Fujjär, Mukadhib and $d \bar{a} l l$, are Hell-dwellers who are welcomed with flames, molten lead, boiling water, and the like. In front of them are the Companions of Right Hand and the Foremost Companions, both of whom will be rescued (Jawādī Āmulī, 3: 1388, 288-289). Thus, the verses (Al-Waqi'a: 10-11) are expressing the hereafter ranking of human beings and given their superiority, they have been expressed as the foremost. Consequently, these verses (Al-Waqi'a: 10-11) have nothing to do with the angels, and they cannot be argued to prove the virtues of the angels over the prophets, and consider them as a pretext for proving such a conclusion.

[2] " On the day when the angels and the Spirit stand arrayed, they speak not, saving him whom the Beneficent allowed and who speak right." (An-Naba': 38) and "And thou (O Muhammad) see the angels thronging round the Throne, hymning the praises of their Lord. And they are judged aright. And it is said: Praise be to Allah, the Lord of the Worlds!" (Az-Zumar: 75). In these verses, the almighty God expresses His greatness by mentioning and naming the angels. If a creature like the Prophet (PBUH) had more honor and virtue than the angels, God would mention them in such verses. As a result, the virtues and superiority of the angels are much greater than the prophets (Amidi, 4: 1423: 229).

\footnotetext{
${ }^{1}$ Sābiqūn

${ }^{2}$ Aṣ̣hāb al-yamīn
} 
Critique: According to the beginning of the verse, "And those who feared their Lord will be led to the Garden in groups" (Az-Zumar: 73). Its context is about how the people of Paradise enter Jannat, where they also see the angels (Jawādī Âmulī, 1387, v. 5: 284-285). The verse is also about the description of the resurrection (Jawādī Āmulī, 1389, v. 5: 440). In this respect, these verses state how perfect human beings, such as the prophets (AS), find and witness the Paradise when they enter it. Therefore, it is not correct to use these verses to prove the virtues of angels over the prophets. It is necessary to note that for the dignity and virtue of a creature such as angels are not comparable to the perfect human being and the prophets (AS) (Jawādī Āmulī, 1384: 371). Because the angels were ordered to prostrate towards Human.

[3] "This is not a human being. This is not other than some gracious angel." (Yusuf: 31). Given that the nature of the angels has virtues, in this verse Yusuf (AS) has become like an angel in having good virtues and not having vices like greed and lust. As a result, the angels have more virtues than him (Ibn Shahr Ashub, 1410: 204). In the metaphor industry, "Simile" has a higher degree of resemblance to what looks like. As a result, angels have more virtues than prophets. Other verses are in this context: " Say: "I tell you not that with me are the Treasures of Allah, nor do I know what is hidden, nor do I tell you I am an angel." (Al-An'ām: 50) and "Your Lord only forbade you this tree, lest ye should become angels." (AlA'rāf: 20) (Rāzī, 1420: 17: 142).

Critique: The context of Qur'anic verses is in such a way that sometimes used the word "angel" for a righteous and good man (Yusuf: 31) and "Satan" for a vicious and evil man: "Evil ones among men and Jinns" (Al-An‘ām: 112) (Jawādī Āmulī, 1389; v. 5: 670). Hence, the verse (Yūsuf: 31) does not imply the superiority of angels to the prophets. Because the purpose of the verse in question is to emphasize the good manners of Yusuf (AS). Assuming there is a simile in this verse, it is the aspect of pseudo-traits and outward beauties. For this reason, Yūsuf may be superior to the angels in the esoteric attributes (Mulla Sadra, 44: 3: 1366). Verse (Al-An'ām: 50) states that the Prophet (PBUH) is not like an angel in all respects and denies complete resemblance. Hence, the verse does not imply that they differ in all attributes (Mulla Sadra, 1366: 3: 44). Because the negation of complete resemblance does not mean allround difference, but it may be shared in some matters, such as perfection virtues. There are two possibilities with regard to the verse Al-A'rāf: 20): One is that this verse does not relate to the time of Adam's prophecy and precedes it. Consequently, the verse does not imply the virtues of angels over the prophets. In other words, angels are virtuous to the human kind in some ways such as power, goodness, beauty, and so on because the angels really act and humans possibly act. For this reason Adam (AS) sought to attain those perfections; though in the end he had more virtues than angels (Mulla Sadra, 1366: 3: 43).

[4] "We have honored the sons of Adam; provided them with transport on land and sea; given them for sustenance things good and pure; and conferred on them special favors, above a great part of Our Creation." (Al-Isrā': 70) According to this verse, humans have been superior and honored over many creatures such as goblins and demons. If man were superior to all creatures, the verse of human superiority over all creatures should be expressed. For this reason, the phrase "all" in the verse was canceled and in vain (Alam al-Hudā, 1998, vol. 2: 333). As a result, angels take precedence over all human beings, including the prophets (AS).

Critique: This verse states that God has exalted the children of Adam (AS) over many beings (Jawādī Āmulī, 1389: 153) and honored him (Jawādī Āmulī, 1384: 284) and interpretation of "Banī Adam." proves this. Thus, the verse is the expression of the virtue of the human species over other species and does not imply the verdict of any kind (Mulla Sadra, 1366: 3: 44). Because the arguments of the Mu'tazila thinkers seek to prove the virtues of the angels over the prophets. While this verse does not 
mention the verdict of some human beings like the prophets, it is a kind verdict. As a result, this argument proves the virtues of angels over humankind, not the prophets.

[5] "Christ disdained not to serve and worship Allah, nor do the angels, those nearest" (An-Nisā': 172). The coming of Christ (AS) before the angels in this verse proves that they have a higher dignity and virtue than the prophets and Christ (Abd al-Jabbār, ND: 214). As in the Arabic conversations, it is said that the sultan's dignity is higher than that of the minister, and his being late in this sentence proves the prevalence of such interpretations in Arabic language and literature. In contrast, the Sultan's precedence to the Minister is not common in such Arabic language interpretations. As a result, Christ's (AS) precedence to the angels in this verse proves their superiority and virtue over the prophets (Rāzī, 1986: 2: 181).

Critique: Christians believe in the Trinity, and the Father, Son (Christ), and the Holy Spirit are known as God. This is why the verse states that Christ and the angels have no denial of godly devotion (Jawādī Āmulī, 1389, v. 3: 67). Hence the verse is as a critique of Christian theory in this regard and therefore does not imply the angels' superiority over Christ (Mulla Sadra, 1366: 3: 42). Another point is that according to the Qur'anic verses, Prophet Jesus (PBUH) was the embodiment of many of the divine blessed names which, according to those manifestations, performed a great deal of astonishing works with the permission of God, because it was the symbol of "Creator" and created the bird; since he was the manifestation of "Healer" and cured the vitiligo, because he was the symbol of "Unseen World" and announced the reserves of the houses, because he was the manifestation of the "Reviving" and revived the dead ... ( Jawādī Âmulī, 1389: 7: 382). In contrast the angels are the symbol of some of the divine names, such as Jamāl (i.e. beauty) or Jalāl (i.e. glory) (Jawādī Âmulī, 1389, v. 3: 54). As a result, Jesus has virtue and supremacy over angels, and so do other prophets.

[6] In the verses of "The Messenger believeth in what hath been revealed to him from his Lord, as do the men of faith. Each one (of them) believeth in Allah, His angels, His books, and His messengers." (Baqarah: 285), "There is no god but He: That is the witness of Allah, His angels, and those endued with knowledge." (Al-Imran: 18), "O ye that believe! Send ye blessings on him, and salute him with all respect." (Al-Ahazāb: 56) and "Allah chooses messengers from angels and from men." (Al-Hajj: 75) In such verses, angels take precedence over the prophets in the Qur'anic word. Such primacy means precedence in their dignity and virtue. A witness for this issue is that when writing the covenant of peace between the Prophet (peace be upon him) and the polytheists, a dispute arose over the primacy of the name. Hence, for Arabs, the primacy of the word implies the primacy of virtue and superiority (Amidi, 1423, v. 4: 229).

Critique: The response to these Qur'anic allegations, which in some Qur'anic verses, the believers preceded the Prophet (peace be upon him) "O ye that believe! Send ye blessings on him, and salute him with all respect." (Al-Ahzāb: 56); however, the believers do not have dignity and virtue on the prophet. Thus it can be said that the precedence of the angels to the prophets (AS) does not mean their virtue and superiority (Rāzī, 1420: 2: 439). In this respect, the Messenger of God (PBUH) reaches a high position in which God does not salute him alone in praise of his Holiness, but also shares all the angels in this salutation: "Allah and His angels send blessings on the Prophet: O ye that believe! Send ye blessings on him, and salute him with all respect." ((Al-Aḥāa: 56): 1) (Jawādī Āmulī, 1385: 8: 139) This is a sign of the high status and virtue of the Prophet Muhammad (PBUH) and therefor the other Prophets over the angels. 


\section{The Lack of Evil Attributes in the Angels and Their Innocence}

The second category of the arguments of the Mu'tazila thinkers in proving the virtues of the angels over the prophets is that there are no evil attributes in the angels. While the prophets may make mistakes. The explanation is that from the perspective of Mu tazila, the Prophet (peace be upon him) may inadvertently commit a mistake (Rāzī1, 1986: 2: 116). But the angels are innocent of any error. On the other hand, the divine prophets are merely infallible. That is, no error, mistake, sin or slip should be issued to them. This infallibility is not only necessary in the matters of mission and prophecy [contrary to the theory of the Mu'tazila theologians], but also in all their personal and social dignity, including belief, morality, behavior, etc., because Every prophet must be trusted by the Ummah and its target audiences, and infallibility in its mission is not sufficient alone to win that trust, but he must always be infallible in all religious contexts in order to win the trust of the people. So the infallibility of the prophets (AS) is not only about receiving, maintaining, and communicating the revelation, but they are innocent of any sin. This general principle is true about all divine prophets, regarding their degrees and ranks. (Jawādī Āmulī, 1379: pp. 57-58). In spite of the nullity of this general principle, argued by the Mu'tazila in this section, their reasons are examined and criticized here:

[1] " To Him belong all (creatures) in the heavens and on earth: even those who are with Him are not too proud to serve Him, nor are they (ever) weary (of His service)." (Al-Anbiyā': 19) This verse proves the angels' superiority and virtue over the prophets in two ways. First, in this verse, God argues that the angels lack arrogance over his worship, that human beings should be like this, and that they should not lead in arrogance and self-glorification in worship of God (Jurjani, 1325: 8: 287). Therefore, angels have superiority and virtue over humans because of the lack of arrogance in angles while it exists in humans. Second, the phrase "even those who are with Him" refers to the angels. Because God is single and is not material, there is no such description of time or place. It is the result of dignity and virtue (Amidi. 1423: 4: 227).

Critique: According to the verses of the Holy Qur'an: The arrogance is not only about angels, but anyone who is close to God and his proximity will be exempt from arrogance: "Those who are near to thy Lord, disdain not to worship Him: They glorify Him, and prostrate before Him." (Al-A'rāf: 206) (Jawād̄̄ $\bar{A} \operatorname{mul} \overline{1}, 1389:$ 3, p. 305) The prophets and divine saints are sincere, so they are out of Satan's reach and free from internal and external obsessions and desires, as the Holy Quran confesses to the Satan's inability and recalls: "(Iblis) said:" Then, by Thy Power, I will lead them all astray. Except Thy Servants amongst them, sincere and purified (by Thy Grace)" (Șād: pp. 82-83) (Jawādī Āmulī, 1387: 1: 211). The other point is that sometimes the position of proximity is that the servant be near God, and sometimes is that the special divine grace be with the servant, and this sentence approves it: the holy prophet (PBUH) asked: "where is God?" He answered: "close to the broken hearts." (Majlesi, 1403: 70: 157) (Jawādī $\bar{A} m u l \overline{1}, 1389: 3$, p. 305). The above argument proves the virtues and superiority of angels over human beings, not the prophets.

[2] The Prophets (peace be upon him), when begging for forgiveness for human beings, first asked the forgiveness of God for themselves: "O my Lord! Forgive me, my parents, all who enter my house in Faith" (Sūrat Nūḥ: 28). "O my Lord! Forgive me and my brother!" (A'rāf: 151), "And ask forgiveness for thy fault, and for the men and women who believe." (Muhammad: 19) and That Allah may forgive thee thy faults of the past and those to follow." (Sürat al-Fath: 2) In contrast, the angels despite the presence of forgiveness towards those who believe, has not asked this for themselves: "Those who bear the Throne (of Allah), and those around it Sing Glory and Praise to their Lord; believe in Him; and implore Forgiveness for those who believe: "Our Lord! Thy embraces all things, in Mercy and Knowledge. Forgive, then, those who turn in Repentance, and follow Thy Path; and preserve them from the Chastisement of the Blazing Fire!" (Ghāfir: 7). Because of this point, angels do not need to be

Criticizing the Qur'anic Anthropology of Mu'tazila, Focusing on the Issue of the Superiority of Angels over the Prophets (PBUT) According to the 
forgiven for not committing sins. In contrast to the prophets (AS) who are not so and therefore are less virtuous than angels (Rāzī, 1986: 2: 188-189).

Critique: The reason that the name of Prophets (PBUH) come first in prayer is that praying for others may give the illusion that the Prophets (PBUH) have a special affinity with God and therefore do not need to be forgiven or prayed.

Therefore, before praying for others, expressing their need and revealing their own inability eliminates any false illusions (Jawādī Āmulī, 1389: 281). Of course, it is imperative to note that forgiveness for the perfect human being and the prophets (AS) is not due to sin and therefore its repulsion, but means returning and paying attention to the Creator. For the consideration of non-God, such as the consideration of angels, or the consideration of revelation or prophecy, is a veil. It is a veil if the prophets pay attention to the authority of their mission, prophecy, caliphate or their position. Because God's secure presence accepts nothing but His witness. Therefore, the prophets are always begging for forgiveness to dispel this kind of considerations (Jawādī Āmulī, 1386: 305).

[3] God, in a verse of the Holy Qur'an, describes the Gabriel as: "Verily this is the word of a most honorable Messenger. Endued with Power, held in honor by the Lord of the Throne. With authority there, (and) faithful to his trust." (Takwīr: 19-21). According to this verse: Gabriel, the Apostle of God to the Prophet (peace be upon him), has the power of the throne, a high status and trustworthiness (Zamakhshari, 1407: 4: 711-712). After these verses, he says about the Prophet of Islam, "And (O people!)Your companion is not one possessed." (Takwir: 22). Therefore, after describing Gabriel with those supreme and complete attributes, He describes the Prophet just as not being an insane. As a result, Gabriel and therefore the other angels have more virtue and perfection than the Prophet of Islam (PBUH) and therefore other prophets (Rāzī, 1986: 2: 192-193).

Critique: The disbelievers and the enemies of Prophet Muhammad (peace be upon him) attributed madness to him: "They say:" $O$ thou to whom the Message is being revealed! Truly thou art mad (or possessed)!" (Al-Hijr: 6).

They also regarded the Qur'an as a myth of the ancestors, not the divine dhikr ${ }^{4}$ :

"The Unbelievers say:" These are nothing but tales of the ancients." (An‘ām: 25). Against these accusations, the glorified God defends the Prophet (peace be upon him) and his Book, and says about his Prophet (peace be upon him): "And (O people!)Your companion is not one possessed." (Takwīr: 22). (Jawādi Āmulī 1388: 343). So He rejects the accusation of the polytheists about the prophet. On the contrary, the Qur'an considers the Prophet of Islam to have very good moral attributes and virtues: "And surely thou hast sublime morals." (Qalam: 4)

In a way that he is a very good example for believers: "Ye have indeed in the Messenger of Allah an excellent exemplar for him who hopes in Allah and the Final Day, and who remembers Allah." (AlAḥāb: 21) As a result, the Qur'an as describing the Prophet (peace and blessings be upon him) has just said that he is not insane.

[4] The angels are infallible because of their immense piety and constant fear, such as: "They all fear their Lord, high above them." (An-Nahl: 50) and "And they stand in awe and reverence of His (Glory)." (Anbiyā': 28) In contrast, the prophets (AS) are not generally innocent and may commit minor sin. Having a great deal of virtue also results in dignity and virtue: " Indeed, the most noble of you in the

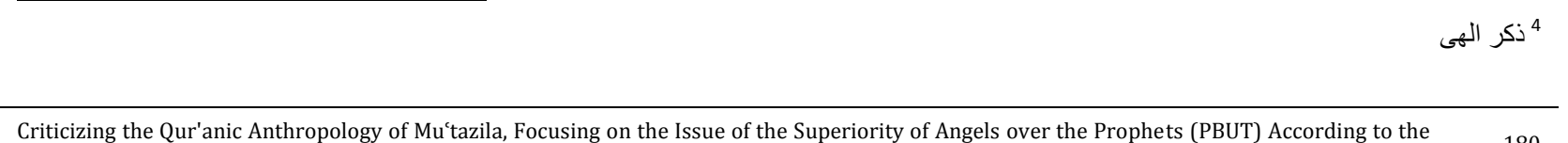


sight of Allah is the most righteous of you." (Al-Hujurāt: 1). Dignity with piety proves that dignity is the effect of piety (Rāzī, 1986: 2: 188).

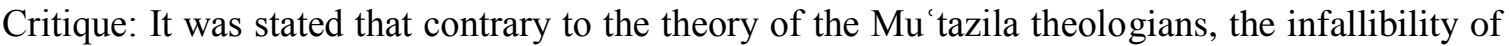
the prophets (AS) is not limited to receiving, maintaining, and communicating the revelation, but they are innocent of any sin. This general principle is true about all the divine prophets with their rank and degree (Jawādi Āmulī 1388: 346), and therefore there is no difference between them. As a result, the second premise of the above argument, namely the Prophet (peace be upon him) is not innocent, cannot be correct and cannot be used in proving the virtues of angels over the prophets.

[5] "But verily over you (are appointed angels) to protect you .Kind and honorable, writing down (your deeds)." (Al-Infițār: 10-11). According to this verse, God has made angels the protector of humans from error and sin. Therefore, the angels themselves are innocent of any wrongdoing (Morteza, 1998: 2: 338). Moreover, God has put angels as His proof for the obedience or rebellion of humans. So their words are more acceptable than humans. As a result, angels are superior to all human beings, including angels (Rāzī, 1986: 2: 189-190). Similarly, theologians and commentators of Mu'tazila argue to another verse in this regard:

"He (alone) knows the Unseen, nor does He make any one acquainted with His Secrets. Except a messenger whom He has chosen: and then He makes a band of watchers march before him and behind him. That He may know that they have (truly) brought and delivered the Messages of their Lord: and He encompasses all that is with them, and takes account of every single thing. (Al-Jinn: 26-28). Commentators have the consensus that the "watchers" in this verse are angels. Thus, the prophets (peace be upon them), in receiving the revelation, are infallible from any error and sin with the help of the angels. As a result, they are more virtuous and superior to the angels (Rāzī, 1986: 2: 190).

Critique: According to what has been said, the infallibility of angels is not incompatible with the complete infallibility of the prophets. Therefore, this argument is also incorrect because it says the Prophets (PBUH) are not infallible and used in proving the virtues of angels over the prophets. Another point is that God Almighty speaks to man and revealed to him through three ways: "It is not fitting for a man that Allah should speak to him except by inspiration, or from behind a veil, or by the sending of a messenger to reveal, with Allah's permission, what Allah wills: for He is Most High, Most Wise." (ashShūrā: 51); either by revelation in which there is no intermediary, or by intermediary, such as that which Moses (AS) heard from the tree, or by an angel sent by the Most High God, to be the sender of revelation. And to send the revelation to his messenger with his permission. In all these stages the speaker is God and the hearer is the perfect man (Jawādī Âmulī, 1389: 7: 128). As a result, Revelation has divisions that in some of them the angel is mediator between God and the prophets (AS), but in others it is not so and God communicates the angel without revelation. As a result, angels are not always mediators of revelation, and this cannot be used to prove their virtue to the prophets.

\section{The Difficulty and Hardship of Angels' Worship}

The third part of the arguments of the Mu'tazila thinkers and commentators in proving the virtues of angels over the prophets (AS) is due to the difficulty of worship in angels and the existence of obstacles in their worship and the elimination of such obstacles in the worship of the prophets. Here is a critique of their arguments:

[1] The human nature is in such a way when facing a trouble like the risk of drowning, calls God sincerely: "Now, if they embark on a boat, they call on Allah, making their devotion sincerely (and 
exclusively) to Him; but when He has delivered them safely to (dry) land, behold, they give a share (of their worship to others)!" (Al-'Ankabūt :65). As there are many difficulties and problems in human life, there is also worship and servitude tools. On the contrary, because of the absence of such things in the angels, their worship is also hard and difficult. Nevertheless, they always worship God and do not disobey His orders: "They celebrate His praises night and day, nor do they ever flag or intermit." (Anbiyā': 20).

As a result, the worship of angels is more virtuous than humans and their desires. The witness for this claim is the story of Adam (AS) in the Qur'an that Allah gave him all the blessings of Paradise except one tree: "And We said:" O Adam! Dwell thou and thy wife in the Garden; and eat of the bountiful things therein as (where and when) ye will; but approach not this tree, or ye run into harm and transgression." (Baqarah: 35) However, Adam (PBUH) disobeyed God's obedience and ate from that tree: "...they tasted of the tree..." (A'rāf: 22). As a result, the obedience and worship of angels have more hardship and suffering than humans and thus their superiority and virtue is better (Fazel Miqdad, 1405: 323).

Critique: The verse (Al-'Ankabūt-65) states that people pay attention to God when they feel threatened and disappointed from material possessions (Jawādī $\bar{A} m u l \bar{\imath}, 1388: 233$ ). Therefore, the absence of obstacles causes attention to God. On the other hand, such things have no way in the world of angels and Incorporeal and their material causes are neglected (Jawādī Āmulī, 1389: 5: 45). As a result, they are always worshiping God. In contrast, the prophets (AS) continue to worship God because of being innocent and not committing a mistake. As a result, the prophets (AS) are more virtuous than angels because of material obstacles while still worshiping God permanently (Mulla Sadra, 1388: 3: 39).

[2] Human nature is always in the process of performing various acts in such a way that the persistence of performing an action makes him tired and bored. In this respect, performing different actions such as different worships is easier than performing one type of action such as a type of obedience and worship. According to the verses of the Qur'an, each of the angels performs a special worship, not the different worships: "They celebrate His praises night and day, nor do they ever flag or intermit." (AșSaaffaat: 165-166). As a result, the worship of God by angels is more difficult than the worship of God by

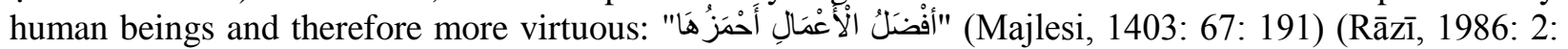
184-185).

Critique: According to verse (Al-Anbiyā': 20), angels constantly worship God and do not get tired of doing so (Jawādī Āmulī, 1389: 7: 527). The philosophical reason for this is that they are singular and that without any material causes and factors. On the contrary, due to the presence of such factors and obstacles in human beings and the Prophet (peace be upon him), their prayers and worships are associated with difficulties and hardships. As a result, their worship is more difficult than the angels' and therefore more virtuous.

\section{Permanent Worship of Angels}

The third part of the arguments of the Mu'tazila thinkers and commentators in proving the virtue and superiority of angels over the prophets (AS) is about the constant worship of angels and the nonpermanent worship of the prophets. Their argument and criticism are as follows:

[1] The worship of angels is permanent and constant because of the verse "They celebrate His praises night and day, nor do they ever flag or intermit." (Anbiyâ': 20). For this reason, their actions are even greater because of the longer life of the angels than humans, and their worship and obedience. As a result, the actions of angels are superior in quantity to those of humans. The quality of the angels is also superior to the worship of human beings (Abideli, 1381: 443), and some Qur'anic verses imply: "They all fear their Lord, high above them." (An-Nahl: 50), "And they stand in awe and reverence of His (Glory)." 
(Anbiyā': 28) and " When terror is removed from their hearts (at the Day of Judgment, then) will they say, 'What is it that your Lord commanded? 'They will say, 'That which is true and just; and He is the Most High Most Great'." (Saba': 23). These verses imply that the angels' worships is with much humility so that they are not only less than the humility in human beings, but more than them. Given the little superiority of the angels' worship and the quality virtue in their worships, their absolute virtue and superiority) is proved over humans and the prophets (AS (Rāzī, 1986: 2: 185-186).

Critique: It has been stated before that angels constantly worship God because of their abstraction from the matter and thus the lack of impediments in them. In contrast, the prophets (AS) are also innocent of any wrongdoing. As a result, they are constantly obeying and worshiping God, and because of the obstacles they have in addition to the constant worship and obedience, they are superior to the angels. The confirmation of this point is that God mentions the worship of some Prophets (PBUH) as the Prophet Jesus Christ (PBUH), along with the worship of the holy angels, says: "Christ disdained not to serve and worship Allah, nor do the angels, those nearest (to Allah)" (An-Nisā': 172). He also introduces him as the honorable and nearest ones to God in the world and in the hereafter: "... His name will be Christ Jesus, the son of Mary, held in honor in this world and the Hereafter and of (the company of) those nearest to Allah." (Al-Imran: 45) (Jawādī Āmulī: 1389: 14: 292).

\section{Angels as the Messengers}

Part four of the arguments of Mu'tazila thinkers and commentators to prove the angels' superiority and virtue over the Prophet (PBUH) deals with the angels as the mediator and messenger of the revelation. Critical interpretation of their arguments is as follows:

[1] The angels are God's messengers to the prophets (peace be upon them), and they convey the revelation of God to them: "He was taught by one Mighty in Power" (an-Najm: 5), "With it came down the Truthful Spirit. To thy heart, that thou mayest admonish" (Ash-Shu'arā': 193-194) and "He doth send down His angels with inspiration of His Command, to such of His servants as He pleaseth." (An-Nahl: 2) The prophets are the messengers of God to their nations and therefore they are superior and virtuous. As a result, the angels have the privilege and virtue of being messenger over the prophets. On the other hand, angels like Gabriel are apostles, whose all nations are the prophets. In contrast, the prophets (AS) are messengers, who's all nations are not prophets. As a result, angels have superiority and virtue over the prophets (Rāzī, 1986: 2: 187).

In other words, the angels are the teachers of the prophets and teach them the religious commandments: "He was taught by one Mighty in Power" (an-Najm: 5). Like Gabriel, who is the mediator between God and the prophets. Therefore, Gabriel (AS) is aware of all the divine laws and he conveys them to the prophets from God. Hence, the angels, including Gabriel, have more knowledge and virtue than the Prophet (PBUH): "Say:" Are those equal, those who know and those who do not know?" (Az-Zumar: 9) (Rāzī: 1986: 2: 191-192).

Critique: It has already been stated that divine revelation is not unique at one time; one part of it is through the Gabriel revelation. Therefore some types of revelation are performed directly by God without the intervention of the angels of revelation. Another point is that God regards the Qur'an as having two Arabic stages and being as Umm al-Kitāb, which are two ends of the universe, one is the world of nature and the other is the farthest point of abstraction, and in the final stage that no one is the intermediate, the only teacher of the Prophet will be God Himself, and there is no anymore an intermediate as the "extreme power", that is, Gabriel. Because in the phase of Umm al-Kitāb and the immediate view, the teacher of the Prophet is directly God, not Gabriel (Jawādī Āmulī, 48 :8 :1385). 
Other verses of the Qur'an also state: "...This Quran hath been revealed to me by inspiration, that I may warn you and all whom it reaches..." (An‘ām: 19) namely this Quran has been revealed to me to warn anyone who receives this message (Jawādī Āmulī, 1384: 55). According to the text and translation of the verse, there is no mention of the mediation of the angel of revelation in this verse.

\section{Conclusion}

Prophetology and angelology are among the major issues mentioned in the Holy Quran, both of which are essential in parallel. Because the guidance of human beings is done by the prophets (AS) and angels are the mediators of the revelation to the prophets. The Holy Quran considers both groups to have many virtues and good attributes and reminds them with great respect. But the question is, when comparing the Quranic verses and the principles and fundamentals of virtue ethics in the Qur'an, which virtues are superior to the others? The Mu'tazila believe that the angels have absolute superiority and virtue over the prophets (AS) because of their being preceded in some Qur'anic verses, the lack of evil attributes and their innocence, the difficulty of worship and being the messenger of God. In contrast, the prophets (AS) are not superior to angels because they are not infallible and are mentioned later in the Qur'anic verses. According to Ayatollah Jawādī Āmulī's interpretive and theological foundations, all arguments face major challenges and are therefore disruptive. Because being late in the Qur'anic word does not mean priority in dignity and virtue, the prophets (AS) have absolute and pervasive infallibility and angels are mediators in some types of revelation, not in all of them.

\section{References}

\section{The Holy Quran}

2. Abd al-Jabbār, Abu al-Hasan (ND), Mutashābih al-Qur'an, Cairo, Dar al-Turath school.

3. Abideli Sayyid Amid al-Din (1381), Ishraq al-Lahout fi Naqd Sharh al-Yaqut, edited by: Ali Akbar Ziyai, Mirath Maktub, Tehran.

4. Alam al-Huda Sayyid Morteza (1998), Amali al-Morteza, Dar al-Fikr al-Arabi, Cairo.

5. Amidi, Sayf al-Din (1423), Abkār al-Afkār fi Usul al-Din, Research: Ahmad Muhammed Mahdi, Cairo, Dar al-Kutub.

6. Fazel Miqdad, Abu Abdullah (1405), Irshad al-Talibin ila Nahj al-Mustarshadin, Research: Sayyid Mahdi Rajaei, Ayatollah Mar'ashi Library Publications, Qom.

7. Ibn Shahr Ashub, Muhammad ibn Ali (1410), Corrected: Shahrestani, Bidar Publishing, and Qom.

8. Jawādī Āmulī, Abdullah (1388), the Moral sacrificed for the Foremost, Qom: Asra.

9. Jurjani, Mir Sayyid Sharif (1325), Sharh al-Mawāqif, Corrected: Badr al-Din Nasani, Qom: Al-Sharif al-Razi.

10. Majlesi, Mohammed Bagher bin Mohammed Taqi (1403), Bihar al-Anwar al-Jamiah Le Dorar Akhbar al-Aemmah al-Athar, Beirut, Dar Īhyā al-Turāth al-Arabī.

11. Mulla Sadra (1366), Tafsir al-Quran al-Karim, Correction: Mohsen Bidar far, Qom: Bidar.

12. Rāzī, Fakhr al-Din (1986), al-Arba'in fi Usul al-Din, Cairo, Al-Zahiri School. 
13. Suyūṭ̂̄, Jalal al-Din (1404), al-Dur al-Manthur fi Tafsir al-Ma’thūr, Ayatollah Marashi Najafi Library, Qom.

14. Zamakhshari, Mahmoud (1407), al-Kashshaf an Haqaeq Qawamiz Tanzil, Beirut: Dar al-Kitab alArabi.

15.— (1386), Ethics in the Qur'an, Qom: Asra.

16._- (1389) Human Expectation of Religion, Qom: Asra.

17._ (1384), Imam Khomeini's Foundation for Peace, Qom: Asra.

18. (1379), the Manifestation of Wilayat in the Verse of Tathir, Qom: Asra.

19._ (1389), The Prophet's Way in the Qur'an, Qom: Asra.

20._ (1), Quran in Quran, Qom: Asra.

21. (1387), Resurrection in Quran, Qom: Asra.

22.- (1384), Revelation and Prophecy in the Qur'an, Qom: Asra.

23. (1388), Rights and Duties in Islam, Qom: Asra.

24. (1388), Shamim Wilayat, Qom: Asra.

25._- (1420), Tafsir al-Kabir, Beirut: Dar Ihya al-Turath al-Arabi.

26._ (1387), Tahrir al-Tamhid, Qom: Asra.

27.— (1389), Tasnim, Qom: Asra.

28. (1385), The Way of the Prophet (peace be upon him) in the Qur'an, Qom: Asra.

\section{Copyrights}

Copyright for this article is retained by the author(s), with first publication rights granted to the journal.

This is an open-access article distributed under the terms and conditions of the Creative Commons Attribution license (http://creativecommons.org/licenses/by/4.0/). 